\title{
Eastern enlargement and differentiated integration: towards normalization
}

\section{Introduction}

Differentiated integration obtains when the European Union (EU) makes treaties and laws whose formal legal validity does not extend to all member states equally. It offers a way out of deadlocked negotiating situations in EU treaty-making and legislation if the heterogeneity of member state preferences and capacities is too large to achieve unanimity or a qualified majority for uniform rules or if domestic nonratification prevents member states from participating in common policies.

Enlargement has always been a major driver of differentiation in European integration (Duttle et al. forthcoming; Schimmelfennig \& Winzen 2014). First, accession negotiations are mainly about temporary differentiation. Because new member states are required to adopt the entire acquis communautaire, and the old member states are required to transfer the entire acquis to new members, all they can negotiate on is a temporary or conditional delay of integration for individual rules. Each accession treaty therefore contains transitional arrangements with derogations from the full and immediate validity of EU rules for the new member states. Such derogations may exempt new member states temporarily from legal obligations to give them more time to adapt. Yet they sometimes also discriminate against the new members by excluding them temporarily from certain rights and benefits of membership. In Eastern enlargement, restrictions on the free movement of labour, initial exclusion from the Eurozone and the Schengen area, and the phasing-in of agricultural subsidies are cases in point.

Second, the accession of new member states has also regularly produced peaks in legislative differentiation after enlargement. To some extent, this is a result of accession treaties affecting the EU's secondary law in addition to treaty law. In addition, however, new member states have often been granted further exemptions or they have used their newly acquired formal decision-making power to obtain them. New member states start their EU membership with a comparatively high level of differentiation, or acquire such a high level in the first years of membership, before they converge with the level of differentiation of the old member states (Duttle et al. forthcoming). Finally, enlargement has generally increased the heterogeneity of EU membership. New member states may have integration and policy preferences and capacities that fall outside the core of the old member states. Enlargement therefore increases the likelihood that European integration will become more differentiated over time. This indirect effect of enlargement should be observable in post-accession secondary legislation and 
treaty revisions. The Polish 2007 opt-out from the Charter of Fundamental Rights is such a postaccession differentiation resulting from the Kaczynski government's extremely conservative integration and policy preferences.

In this paper, we analyse the 'normalization' of the new member states' differentiated integration as an indicator of the EU's internal integration capacity. We understand normalization in two ways. For one, we examine quantitative normalization: the more the new member states approximate the level of comparable old member states, the more effectively they are integrated into the EU. In addition, we take normalization to mean that the new member states are differentiated for the same reasons and in the same areas as the old member states. The dominant correlates of differentiated integration are wealth and national identity - does that also hold for the new member states?

This paper will report and analyse data on the differentiated integration of the EU member states that joined in 2004 and 2007. We ask whether the new member states' initial differentiated integration has decreased - and to what extent they have obtained new differentiations during the first years of their membership. In order to approximate the counterfactual scenario of differentiated integration in the absence of recent enlargement, we compare the Eastern new member states to the Southern old member states, to which they are structurally most similar. In each case, we distinguish between 'exemptive differentiation' - favouring the new member states by postponing legal obligations of membership - and 'discriminatory differentiation' excluding the new member states from desired rights and benefits of EU membership and legislation (Schimmelfennig 2014). In addition, we explore variation among the Eastern new member states and across EU policies.

We argue that the post-accession differentiated integration of the new member states is, indeed, a story of normalization. Both with regard to the extent and the causes of differentiation, the new member states have increasingly converged both with the old member states and with established patterns of differentiation. We even see that, in comparison with the Southern member states, Eastern member states have had 'too low' levels of differentiation. Finally, even though new member states were generally treated highly equally by the EU in terms of differentiations, we find that both poorer new member states and member state with a stronger national identity have been slightly more differentiated in some policy areas. This is again in line with established patterns of differentiation in the EU. In sum, during roughly the first decade after enlargement, the new member states have become 'normal' member states with regard to differentiated integration. By the same token, our analysis shows that the initial differentiation has resulted from a temporary enlargement effect and that EU legal 
integration capacity has proven robust. Some uncertainty remains as to the persistence and future development of selected cases of differentiation such as the Eurozone opt-outs of several new member states.

\section{Explaining the differentiated integration of new member states}

According to the basic story in the literature (see, e.g., Dyson \& Sepos 2010: : 5-6; Jensen \& Slapin 2012; Kölliker 2006; Leuffen et al. 2013; Majone 2009: : 221), differentiated integration is best understood as an institutional response to the increasing heterogeneity of member state preferences (willingness) and capacities (ability) resulting from both the widening and the deepening of the EU. Willingness consists in having an interest in participating in the internal market and the common policies of the EU, and in being prepared to transfer state competences to the supranational level. Ability results from the political system as well as economic and governance capacity. The EU requires members to be democracies, ruleof-law systems, and market economies, to be able to withstand the pressures of the internal market, and to implement supranational rules effectively. ${ }^{1}$

Enlargement is prone to increase the heterogeneity of the EU's membership. Some new member states were initially 'unwilling' because they were sceptical of giving up state autonomy - and sufficiently wealthy and economically successful to be able to afford refraining from integration (Mattli 1999). This applied, for instance, to Britain, the Nordic countries, and Switzerland initially (Gstöhl 2002). Others were willing but lacked capacity. This was initially the case for Southern European countries and has also generally been true for the Central and Eastern European accession candidates: relatively poor transition countries with uncertain governance capacity. In both cases, the increased heterogeneity generates bargaining about the terms of accession during the enlargement process. As a result, accession treaties regularly contain 'transitional arrangements', which either grant the new member states temporary exemptions from legal obligations of EU membership or deprive them temporarily from certain rights and benefits. In the following sections, we present theoretical arguments and empirical findings on the factors influencing the amount, kind, and duration of such transitional arrangements. They help us to assess the normalization of differentiated integration in the new member states. 
The baseline: temporary differentiation and equal treatment in enlargement rounds

As a baseline, we start from two general patterns of differentiated integration among new member states. First, differentiations based on accession are more short-lived than differentiations based on treaty revisions. In contrast to treaty-based differentiations negotiated among existing member states, they are not only generally defined as temporary and transitional but also expire faster on average (Schimmelfennig \& Winzen 2014). Second, new member states joining in the same enlargement round enjoy fairly equal treatment. To some extent, this can be explained by the fact that enlargement rounds consist of countries with similar historical legacies, political and economic conditions. Still, 'enlargement round' outperforms all other country characteristics in explaining the amount of differentiated integration of new member states (Schimmelfennig 2014).

These baseline patterns can be explained by the legal construction of the EU (Schimmelfennig 2014). First, legal systems are normatively and institutionally biased against differentiation. Differentiation may be acceptable to facilitate the integration of new member states for a limited period of time but undesirable for the long term or even permanently. Second, EU negotiators are constrained to treat candidates equally because European treaty law is based on the principle of state equality. As a consequence, exemptions granted to one country are also granted to other candidates if they so demand - at least within the same enlargement round. It also means that individual candidates are not singled out for discrimination but that temporary exclusions are applied to all countries of an enlargement round. Additionally, equal treatment is likely to facilitate and speed up enlargement negotiations because all candidate countries understand that EU negotiators are unwilling to allow tailor-made transition arrangements and that candidates will not reap private gains from separate negotiations.

Temporary differentiation and equal treatment set the stage in favour of a quick approximation of differentiation integration between new and old member states, and against strong differences in differentiated integration among the new member states. On this basis, we can now turn to factors potentially explaining variation in the duration of transitional arrangements and in the amount and kind of differentiated integration across the new member states.

Sources of variation: wealth and identity

Variation in differentiated integration among the new members can be attributed to their preferences and capacities - and to their bargaining power vis-à-vis the old member states. Studies of differentiated 
integration show that wealth and identity are major correlates of differentiated integration among EU member states (Schimmelfennig \& Winzen 2014; Winzen 2016; Winzen \& Schimmelfennig forthcoming). First, poorer member states and member states with a more exclusive national identity have more differentiated integration. Second, wealth has a particularly strong effect on the initial differentiation of new member states, whereas national identity matters more for treaty revisions and legislation among the existing member states. Third, differentiated integration now mainly affects policies related to core state powers (such as monetary policy, Schengen/Dublin, and justice and home affairs). Similar patterns among the new member states of the Eastern enlargement would corroborate the normalization argument.

In a bargaining perspective, Christina Schneider (Plümper \& Schneider 2007; Schneider 2009) analyses transitional arrangements as instruments to overcome intergovernmental deadlock in accession negotiations deriving from conflict about the distribution of gains and losses from enlargement. Old member states, or powerful interest groups in these states, fear economic and financial losses or a reduction in governance efficiency as a result of market integration with the new member states (e.g. resulting from the opening up of labour markets), the redistribution of EU funds (e.g. in agriculture or regional policy), or weak implementation capacity (e.g. by expanding the Schengen regime before effective border controls are in place). Likewise, new member states fear popular opposition against membership if, for instance, citizens from the old member states are allowed to buy homes and land without restrictions. Differentiated integration is an instrument to placate the relative losers - ideally until preferences, economies and administrative capacities have converged sufficiently to minimize their losses.

Relatively poor candidates produce the strongest concerns about 'integration capacity' and redistribution and thus create demand among the old member states for differentiation in the form of discriminatory exclusion. In addition, the old member states also possess the bargaining power to impose such discriminatory exclusion on poorer candidates. As a result of asymmetrical interdependence, prospective new member states are normally in a weak bargaining position vis-à-vis the EU. Their markets are much smaller than the internal market, and bilateral trade with the EU is much more important to them than it is to the EU. As a consequence, candidate countries have more to gain from EU membership than the EU has to gain from accession of the candidate country, and candidate countries in the vicinity of the EU usually do not have credible outside options at all. This is especially true for the Central and Eastern European countries (Moravcsik \& Vachudova 2005). Under these circumstances, the old member states are generally able to decide on the terms of the transitional 
arrangements with new member states. Whereas wealthier countries are more able to afford remaining outside the EU, poorer and badly governed countries have an overwhelming interest in market access, transfers from EU funds, and EU regulatory and administrative capacity - and therefore accept discrimination more readily. By the same token, poorer new member states lack the bargaining power to realize exemptions upon accession. We therefore hypothesize:

(H1a) The poorer a new member state is, the more likely it is subject to differentiated integration.

(H1b) The poorer a new member state is, the more likely it is subject to discriminatory differentiation and the less it benefits from exemptive differentiation.

Candidates may have non-material motivations to seek opt-outs, too. Some member states and societies have principled objections to transferring powers to the EU for fear of hollowing out national sovereignty (Schimmelfennig \& Winzen 2014; Winzen \& Schimmelfennig forthcoming). Sovereignty concerns are prone to arise most strongly in member states with strong national identities. Earlier research has shown that exclusive national identities reduce support for European integration (Carey 2002; Hooghe \& Marks 2005). Hooghe and Marks further argue that exclusive national identities are likely to be activated if the scope and depth of integration increase perceptibly (Hooghe \& Marks 2008: : 13). It is therefore plausible to assume that countries with stronger national identities are more likely to demand exemptions and oppose discrimination because of their sovereignty-oriented preferences. They may also be more capable of realizing their preferences as governments can point to sceptical public opinion to achieve a better deal in accession negotiations.

Even though earlier research has shown that national identities do not matter systematically in the accession context, we think there are good reasons to explore their effects here. On the one hand, these 2004 and 2007 enlargements occurred in a more deeply integrated and more politicized EU than earlier enlargements. We may therefore find an empirical relationship that was not apparent before. On the other hand, our analysis includes the post-accession period, new legislation, and the revision of treaties.

(H2a) The stronger the national identity of a new member state is, the more likely it is subject to differentiated integration.

$(\mathrm{H} 2 b)$ The stronger the national identity of a new member state is, the less likely it is subject to discriminatory differentiation and the more it benefits from exemptive differentiation. 
The likelihood that identity and sovereignty concerns arise varies across policies. Genschel and Jachtenfuchs (2014: :10) define 'core state powers' (such as a state's army, police and justice system, currency, or public administration) as those functions and policies that have particularly strong 'institutional significance for state building' and are thus closely linked to sovereignty. The integration of such policies is more likely to trigger identity politics, leading to politicization and differentiation (Schimmelfennig et al. 2015; Winzen \& Schimmelfennig forthcoming). It is also likely to increase old member state concerns about the governance capacity of new member states. Because identity and sovereignty concerns are normally more principled than concerns about economic and technical policies, we further assume that new member state differentiations in the area of core state powers are more durable and will increase as they participate in treaty revisions and new legislation.

(H3) Policies in the area of core state powers are more likely to be and remain differentiated.

Finally, candidates are in a particularly vulnerable and dependent position when they negotiate accession. In this time period, old member state bargaining power is at its peak. Once they are members, however, they are protected by the principles of non-discrimination and legal equality, participate in the elaboration of new rules and possess voting power. The consensus orientation of the Council of Ministers further strengthens any member state's ability to avoid detrimental legislative outcomes (e.g. Heisenberg 2005; Smeets 2015). We assume that it is particularly difficult to impose discriminatory rules on new member states once they have joined the EU.

(H4a) New member states are less subject to discriminatory differentiation after accession.

(H4b) By contrast, new member states are more likely to attain exemptions after accession.

In line with the normalization argument, we expect that the differentiated integration of the new member states will align itself with that of the old member states. In particular, their level of differentiation, and the mix of exemptions and discrimination, should approximate that of similar old member states. Moreover, the normalization argument implies that differentiation among the new member states varies with their wealth and national identities.

\section{Data and research design}

Our investigation relies on the EUDIFF1 (primary law) and EUDIFF2 (secondary law) datasets on differentiated EU integration and legislation (Duttle et al. forthcoming; Schimmelfennig \& Winzen 2014). The EUDIFF1 dataset tells us, year-by-year, whether a country is bound by any given article in the EU's 
main treaties. It also records any treaty-law differentiation that enlargement treaties create. Our analysis aggregates this data into 'differentiations'. Opt-outs from individual treaty articles that enter into force and end at the same time and apply to the same policy area constitute a differentiation. Thus, for instance, a country's opt out from the Schengen area, which is regulated in over 150 treaty articles, is coded as one differentiation. The EUDIFF2 datasets tells us, again on a yearly basis, whether any given secondary legal act that is currently in force fully binds a given country. It shows, for instance, whether any particular directive that existed in, for instance, 2005 contained a differentiation for, for instance, Poland or Latvia. If a country is not bound by at least some parts of a legal act, we say that it has a differentiation.

Based on these raw data, we have manually identified whether each primary and secondary law differentiation is an exemption or discrimination. A differentiation that withholds or limits membership or legislative rights and benefits from a new member state is discriminatory, such as Bulgaria's and Romania's exclusion from the Schengen area, or transition periods regarding the free movement of workers from new member states. A differentiation that limits membership or legislative obligations and burdens on a new member state is an exemption, such as transition periods in competition law granted to new countries in order to make state aid for their heavy industries possible.

In order to investigate variation across policy areas, we begin with the disaggregated areas identified in the EUDIFF1 and 2 datasets. These areas are derived from the titles of the treaty sections in which individual treaty articles are, or in which the legal bases of legislation are. Since these areas are numerous, we aggregate them into four large policy domains: the market, encompassing the four freedoms and adjacent areas such as competition; agriculture; regulatory policies such as health, consumer protection or environment; and core state powers, including monetary union, foreign affairs, justice and internal security policies (for further details, see Duttle et al. forthcoming).

The analysis of primary law examines discriminations and exemptions in the 2004 and 2007 accession treaties, and traces their development in the subsequent years. This analysis does not make an explicit comparison to establish whether the level of discrimination or exemption of the newcomers is excessively high or low. First, only new members can obtain differentiations from accession treaties, while other countries do not even have that opportunity. ${ }^{2}$ Second, a comparison through time is not convincing. The previous enlargement dates back nine years and, with Austria, Finland and Sweden, integrated entirely different (wealthier, better-governed, and democratically consolidated) countries. The Southern enlargement happened in the 1980s, still at the time of the European Communities, before 
the Single Market Programme and the EU's acquisition of competences in core state powers. Thus, we limit ourselves to saying how much and what kind of differentiation resulted directly from the accession treaty.

The analysis of secondary legislation investigates the level of discrimination and exemptions of new member states in every year since their accession in 2004/2007. Let us, however, underline the importance of an appropriate benchmark for comparison: What level of differentiation should we have expected from a given new member states, had that state not recently joined the Union? Expecting no differentiation at all could be inappropriate given that old member states might be subjected to a certain number of exemptions and discriminations in legislative politics. Of course, even if comparable old member states experience similar patterns of differentiation, we could still say that newcomers are being discriminated or exempted - however, it would be inappropriate to conclude that they are treated in this way because they are new member states.

In order to establish an appropriate benchmark, our strategy is to compare the new member states to the most comparable old member states: the Southern countries, Greece, Portugal and Spain. As the Central East European countries, the Southern group is poor economically and suffers from weak governance capacity, compared to the Union's North Western members. It also relies comparatively a lot on agriculture. It is obvious that this empirically-oriented strategy does not ideally approximate a counterfactual comparison. First, however, we suggest that an empirical benchmark, even if imperfect, is preferable over a thought experiment that, in this context, must be seen as highly speculative. Second, the comparison to the South is more appropriate than, say, to a rich Northern European member state. Third, while the Southern countries differ from the Central and East European newcomers, they do so in ways that we can clarify and potentially exploit analytically: On average, the 2004/2007 cohort is poorer, has more nationally-oriented populations, significantly more heavy industry, and, in some cases, slightly larger agricultural sectors (see Error! Reference source not found., Error! Reference source not found.,

Error! Reference source not found., Error! Reference source not found.). Given these differences, one would generally expect that the Eastern enlargement countries obtain more differentiations than the South (see H1a and H2a). In the case of such an outcome, it would be difficult to establish whether their newcomer status or their domestic conditions account for the discrepancy to the South. An outcome in which the East faces fewer differentiations would, however, be more clearly attributable to their recent accession, and certainly not the result of domestic conditions being different from the South. 


\section{Patterns of treaty-based discrimination and exemptions}

Beginning the empirical analysis at the treaty-level, Error! Reference source not found. shows the development of the treaty-based differentiation of the new member states since 2004. The figure excludes Cyprus and Malta because these two countries are not easily comparable to the others, due to their size, island status, difficult security situations (Cyprus), relatively affluent economies, and relatively Europhile populations. But including the two countries would have confirmed the main trends (not shown here). ${ }^{3}$ The left-hand panel shows that the 2004 newcomers had six differentiations each, except for Slovenia, which had five. The two additional differentiations of Bulgaria and Romania relate to the Prüm Convention that had not yet been signed at the time of the 2004 enlargement. Otherwise the 2007 newcomers' opt-outs are the same as for the 2004 group. In the appendix, we provide disaggregated information by country, discriminations and exemptions (Error! Reference source not found.). The six differentiations all countries share encompass four cases of discrimination and two exemptions:

- Exclusion from the common currency;

- Exclusion from the Schengen area;

- Restrictions regarding the free movement of workers;

- $\quad$ Restrictions regarding the freedom to provide services;

- Exemptions from competition law, in particular regarding state aid;

- Exemptions from capital mobility, in particular regarding the acquisition of land and property by foreign buyers.

The left-hand panel of Error! Reference source not found. further shows that the treaty-based differentiations of the 2004 cohort have gradually expired. The new member states have acceded to the Schengen area and, in some cases, the common currency. Free movement discriminations and exemptions have largely expired. In 2013, only some capital mobility exemptions and Eurozone discriminations remain. Note, moreover, that it is unclear whether the latter can still be understood as discriminatory. Whereas the Czech Republic, Hungary, and Poland have initially been excluded from monetary union, they have become highly reluctant to work towards Eurozone membership in the meantime. Bulgaria and Romania lag behind. Even though they have joined the Prüm Convention, discriminatory differentiation remained in 2013 regarding the Eurozone and Schengen, the free movement of workers and services, while exemptions in competition policy have expired. Preferential treatment regarding capital mobility still applied in Bulgaria in 2013. Finally, there is some variation in the speed in which differentiation has expired. Overall, however, except for Bulgaria and Romania, there 
clearly is a common cross-country trend towards uniform integration that had almost come to an end in 2013, eight years after the 2004 enlargement (for patterns disaggregated by country, see Error! Reference source not found.).

$<$ Figure 1 here>

One might ask whether new differentiations have compensated for the dissipation of accession treatybased differentiation. In the right panel, we examine the level of new members' differentiation, taking into account opt-outs arising from treaties that entered into force after accession, the Prüm Convention (for the 2004 cohort), the Lisbon Treaty, the European Stability Mechanism Treaty (ESM) Treaty, and the Treaty on Stability, Coordination and Governance (TSCG). Because doing so means that the opportunities for countries to acquire differentiations vary over time, we divide the absolute numbers of opt-outs by the number of policy areas under EU jurisdiction in a given year. If we treat each policy area as a differentiation opportunity, the figure shows the share of differentiation opportunities that 2004/2007 accession countries made use of in a given year. Treating policy areas as opportunities slightly underestimates the decline of differentiation over time because a country's number of differentiations in a policy area can grow over time - for instance, if they do not participate in the Eurozone from the start, and then also stay out of additional changes in Eurozone rules introduced in the Lisbon Treaty. The righthand panel nonetheless largely confirms the downward trend. There is a hike in 2006 because not all 2004 newcomers immediately acceded to the Prüm Convention. Further, the decline of differentiation slows in 2010 with the entry into force of the Lisbon Treaty, due to follow-up Eurozone differentiations and a Polish opt-out from the Charter of Fundamental Rights. Finally, differentiation has slightly increased recently as only Eurozone members adopted the ESM treaty and not all Central and East European states had signed the TSCG treaty by 2013. Many have done so since, however, and Latvia and Lithuania have acceded to the Eurozone so that the downward differentiation trend continues.

Considering variation across policy areas, the discussion highlights several points (not shown in figures). First, treaty-based differentiation exists in the market and in core state powers but not in the EU's regulatory and agricultural policies. Transition periods regarding agricultural subsidies are regulated in the appendices of the enlargement treaty but implemented through opt-outs from secondary legislation. The EU's substantive regulatory policies rely on legislation, while the treaties only contain legal bases. 
Second, exemptions exist only in the market but not in core state powers, except for Bulgaria and Romania initially not joining the Prüm Convention. Discrimination exists in both domains but, in the market, it has disappeared entirely for the 2004 cohort, while not all countries have joined the Eurozone yet. In the case of Bulgaria and Romania, discrimination persists in the market and in core state powers. H3 expected differentiation to be more likely and long-lasting in core state powers than in other domains. That discrimination has disappeared almost entirely in the market but not in core state powers supports this view. However, developments in the market question H3. There, some capital mobility and free movement differentiations persist. Moreover, we do not see more differentiation in core state powers overall.

Error! Reference source not found. explores whether new member states' exemptions from the market, and discriminations in core state powers, correlate with per capita national wealth and prevailing exclusive identity conceptions in the population. As noted, variation between countries is mainly the result of the different duration of differentiation since accession so that the outcome of interest in the figures effectively is the speed with which countries move towards uniform integration. The figures confirm that there is very limited variation overall and that candidates of the same enlargement round are treated fairly equally. There is a slight tendency, in line with $\mathrm{H} 1 \mathrm{~b}$, for poor countries to benefit from longer-lasting market exemptions and to suffer from longer-lasting discrimination in core state powers. However, these tendencies are strongly driven by the Eastern front-runner towards uniformity, Slovenia, and the two laggards, Bulgaria and Romania. We do not consider market discrimination and core state power exemptions because there is nearly no cross-country variation at all in both cases.

In conclusion, while there is some variation across policy areas and countries, the basic story at the treaty level is one of equal treatment and temporary differentiation, in line with our baseline expectation. Bulgaria and Romania still defy this tendency to some extent although these two countries have also followed a downward differentiation trajectory so far. The two policy domains in which differentiation may prove lasting are capital mobility and Eurozone membership. In the case of Eurozone membership, a core state power that has long been highly differentiated in the EU, this is understandable. The persistence of selected capital mobility exemptions, however, is not common in light of other member states' experiences and, thus, a finding that runs counter to the 'normalization' argument. 


\section{Patterns of discrimination and exemption in secondary legislation}

Error! Reference source not found. shows the average overall level of differentiation of the 2004 and 2007 accession countries, in comparison to the other cohorts. For the older cohorts, the figure shows the last years of a long-term decline in differentiation that results in particular from the consolidation of the EU's market legislation. However, widespread exemptions from core state powers, notably justice and home affairs legislation, distinguish the Northern cohort (Duttle et al. forthcoming; Winzen 2016). The level of differentiation of the 2004 cohort increases slightly. Bulgaria and Romania have fewer differentiations but follow a similar trajectory. By 2012, the Central East European countries converge with the Southern cohort that, we argued, constitutes the most appropriate standard of comparison. Statistically, the 2004 cohort is no longer significantly different from the South by 2009 - the same holds for Bulgaria and Romania as of 2012. However, also note that the new member states did not have as many differentiations as the South at the time of their accession. We explore and disaggregate these patterns in this section.

$<$ Figure $2>$

Error! Reference source not found. shows discriminations and exemptions of the 2004 and 2007 accession countries, and the Southern member states. Comparing the Eastern to the Southern countries, the former suffer from more discrimination throughout our period of analysis. The overall level of discrimination is very low, however, and the difference results from the East's agricultural transition periods as well as some countries' non-participation in Eurozone related legislation. In line with $\mathrm{H} 4$, discrimination in post-accession secondary legislation has been much less pronounced than discrimination in the accession treaties. Moreover, exemptions have been more frequent in the postaccession period than discriminations.

$<$ Figure $3>$ 
Additionally, the new member states do not benefit from as many exemptions as the Southern countries. However, while they maintain a roughly stable number of exemptions until the end of 2012, Greece, Portugal and Spain's opt-outs shrink gradually. Unlike the new members, the Southern countries follow an EU-wide trend towards uniformity that can be shown to exist in market and agricultural legislation (Duttle et al. forthcoming). By 2012, Poland, Latvia, and Lithuania had reached similar levels of exemption as the Southern countries. Bulgaria's and Romania's discriminations and exemptions generally resemble those of the least well-positioned countries of the 2004 group. The two panels in the lower half of Error! Reference source not found. further show that the reason for the converging exemption trends of the South and East is the decline of Southern exemptions. The Eastern countries obtain more exemptions (and discriminations) in their initial membership year, but afterwards the differences are very small. It is clearly not the case that the new member states successfully negotiate exemptions (or unsuccessfully oppose discrimination) at a notably higher rate than the Southern countries. This is an indication of normalization. Yet, the exemptions that they obtain from legislation persist during our period of analysis, whereas the Southern states (and the EU more generally) are moving on a trajectory towards uniformity. It remains to be seen whether the new member states will join this trajectory as soon as the rest has 'caught up' with their low exemption levels.

$<$ Figure $4>$

Interpreting these observations, keep in mind that, in a bargaining perspective, the difference in secondary law differentiation between the South and East could plausibly result from the latter countries' somewhat weaker, more agricultural, and industrial economies. That the poorer Eastern cohort was more discriminated and benefited less from exemptions during the period of observation is in line with Hypothesis 1b. Even though direct discrimination is weak after accession (legislative discriminations are very rare in any case), the 2004 and 2007 cohorts clearly suffer from excessively low levels of exemptions for most of the period that we investigate - i.e. from what one could label indirect discrimination'. Only in 2013 could some new members be said to have overcome indirect discrimination.

Error! Reference source not found. disaggregates exemptions, the more frequent type of legislative differentiation, into policy domains. The patterns in the market domain correspond to what has been 
described so far. This matters because the market is also an area in which the accession treaties have offered newcomers exemptions regarding capital mobility and competition policy. The lack of legislative exemptions might be the mirror image of these treaty-based opt-outs. In agricultural policies, the trends are also similar to the aggregate picture but the levels of exemption differ. The Southern states never had clearly more exemptions than the new members, and their levels fall below that of the 2004 cohort in late 2000s. In regulatory policies, finally, the Southern decline is more moderate but the Eastern countries in fact accumulate exemptions towards the end of the 2000s. In sum, the indirect discrimination observed at the aggregate levels exists in the market and regulatory but not in agricultural policies. The EU's regulatory policies are the only ones in which the new member states gain exemptions, instead of 'waiting' for the rest of the Union to decline to their levels. The panels also show that the absolute number of exemptions is very low in all policy areas.

Finally, we explore whether accession countries' exemptions or discriminations correlate with their wealth and citizens' identity conceptions. However, we do not find strong patterns (see Error! Reference source not found. and Error! Reference source not found.). Error! Reference source not found. presents the clearest finding. In the area of core state powers, there is a tendency for less discrimination of countries that are rich, and more discrimination of countries that have populations with exclusive identity conceptions. As noted, discrimination in this area predominantly reflects treaty-based opt-outs from the Eurozone. Accordingly, the patterns are similar except that the identity effect was weaker on the treaty level. That there is such an effect should not be interpreted to mean that old member states exclude nationally-oriented newcomers from core state powers. It rather indicates that Eurozone optouts, while initially clearly discriminatory, have become increasingly ambiguous to categorise. Whether, for instance, the Czech Republic and Poland would be prevented from joining the Eurozone today, whether they prefer not to, or whether both logics reinforce each other, is unclear.

$<$ Figure $5>$

\section{Conclusion}

In this paper, we have examined the EU's integration capacity regarding new member states' differentiated integration and explored variation across member states and policies. In general, the EU's integration capacity has been considerable. Treaty-based differentiations for the new member states 
have gradually declined over time, even if we take into account treaties concluded after their accession. Secondary-law differentiation has been low for the new member states and largely stable since accession. Besides a selected number of persistent capital mobility differentiations, the main remaining divide is between Euro area and non-Euro area countries among the 2004 and 2007 intake - a divide that we find among the older member states as well. Comparing the new member states to the Southern member state reference group, we find that legislative discrimination is low in both cases and legislative exemptions converge over time. These developments testify to the gradual quantitative normalization of the new member states' initial differentiations and to a high degree of legal uniformity after accession. Since the convergence of Southern and new members stems primarily from declining Southern differentiation (which in turn reflects a system-wide trend towards uniformity), an open question is whether the Eastern newcomers will now also follow this downward trajectory or rather maintain a stable share of legislative exemptions.

In comparison with the Southern member states, we also find that legislative differentiation has been low. The Eastern cohort has obtained slightly more discriminatory differentiation and clearly less exemptive differentiation than the Southern cohort in the post-accession period. This suggests that the Eastern new members have temporarily suffered from both direct and (mostly) indirect discrimination in comparison with the South, potentially because they were poorer and therefore possessed weaker bargaining power ( $\mathrm{H} 1 \mathrm{a})$. As noted, this difference has declined over time.

$\underline{\text { In line with our assumption that member states from the same enlargement round are treated similarly, }}$ we observe little variation in differentiation. However, we find some evidence for hypothesis 1 that wealthier countries incur less discrimination in core state powers, and benefit from fewer market exemptions. Contrary to expectations, countries with stronger national identities are more rather than less discriminated in the area of core state powers. However, this is mainly an effect of differential Eurozone membership-it has become hard to distinguish discrimination and exemption in this area as non-members often do not work actively towards adopting the common currency. The pattern points to normalization too in the sense that old member states with strong national identities are more likely to opt-out from the integration of core state powers.

In sum, notwithstanding selected exceptions and uncertainty regarding the future trajectory of differentiation, the overall picture is one of normalization. The new member states have not only been converging to 'normal' levels of differentiated integration in the years after accession; they have also been differentiated for similar reasons than the old member states. In particular, even though country

Deleted: Generally, there is little variation in differentiated integration across the new member states. This is in line with our assumption that member states from the same enlargement round or related enlargement rounds incur similar discrimination and exemptions. The little variation we do observe among the generally similar treatment of the new member states points again to a relative poverty effect. In line with hypothesis 1 , we find some evidence that wealthier countries incur less discrimination (in the area of core state powers) and benefit from less long-lasting exemptions (in the area of the internal market). This corroborates the more general observation that differentiated integration in the context of accession affects poorer countries disproportionately. Hypothesis 2a is not supported because countries with stronger national identity are more rather than less discriminated in the area of core state powers. It must be said, however, that this is mainly an effect of differential Eurozone membership and that it becomes increasingly hard to distinguish discriminatory from exemptive differentiation in this area, as current non-Euro area new member states most often choose not to work actively towards EMU membership rather than being kept out. This pattern again matches the old member states well: countries with stronger national identities are more likely to opt-out from deepening in the area of core state powers. In this respect, we can again speak of a normalization of new member state differentiated integration. Finally, and again in line with general patterns of differentiated integration in the EU, we observe that the area of core state powers is particularly prone to differentiation. While the 2004 and 2007 accession treaties included core state power and market differentiation, differentiated integration in core state powers has proven to be most durable, even though we also find persistent market differentiation in some countries. It is the only area in which new member states have initially been subjected to treaty-based discrimination without being 'compensated' by exemptions in the legislative process; and it is here that variation in wealth and identity among the new member states has produced the clearest effects. ๆ 
differences are clearly limited, the analysis indicates support for the general pattern that poorer countries have higher levels of differentiation upon accession and that core state powers are most prone to differentiation. Moreover, the divide between euro area and non-euro area countries has become the most important divide among both old and new member states. EU integration capacity has thus proven to be strong - yet, this does not imply fully uniform integration but rather refers to the tendency that Central and Eastern European countries have increasingly shifted from patterns of differentiation typical of new member states to patterns of differentiation typical of old member states.

\section{References}

Carey, S. (2002) 'Undivided Loyalties: Is National Identity an Obstacle to European Integration?', European Union Politics 3(4): 387-413.

Duttle, T., Holzinger, K., Malang, T., Schäubli, T., Schimmelfennig, F. and Winzen, T. (forthcoming) 'Opting out from European Union Legislation: The Differentiation of Secondary Law', Journal of European Public Policy.

Dyson, K. and Sepos, A. (2010) Differentiation as Design Principle and as Tool in the Political Management of European Integration. In: K. Dyson and A. Sepos (Eds.) Which Europe? Basingstoke: Palgrave, pp. 3-23.

Genschel, P. and Jachtenfuchs, M. (2014) Introduction: Beyond Market Regulation. Analysing the European Integration of Core State Powers. In: P. Genschel and M. Jachtenfuchs (Eds.) Beyond the Regulatory Polity? The European Integration of Core State Powers. Oxford: Oxford University Press, pp. 1-23.

Gstöhl, S. (2002) 'Scandinavia and Switzerland: small, successful and stubborn towards the EU', Journal of European Public Policy 9(4): 529 - 549.

Heisenberg, D. (2005) 'The institution of 'consensus' in the European Union: Formal versus informal decision-making in the Council', European Journal of Political Research 44(1): 65-90.

Hooghe, L. and Marks, G. (2005) 'Calculation, Community and Cues: Public Opinion on European Integration', European Union Politics 6(4): 419-443.

Hooghe, L. and Marks, G. (2008) 'A Postfunctionalist Theory of European Integration: From Permissive Consensus to Constraining Dissensus', British Journal of Political Science 39(01): 1-23.

Jensen, C.B. and Slapin, J.B. (2012) 'Institutional hokey-pokey: the politics of multispeed integration in the European Union', Journal of European Public Policy 19(6): 779-795.

Kölliker, A. (2006) Flexibility and European Unification: The Logic of Differentiated Integration, Lanham: Rowman and Littlefield.

Leuffen, D., Rittberger, B. and Schimmelfennig, F. (2013) Differentiated Integration, Basingstoke: Palgrave.

Majone, G. (2009) Europe as the Would-Be World Power. The EU at Fifty, Cambridge: Cambridge University Press.

Mattli, W. (1999) The Logic of Regional Integration: Europe and Beyond, Cambridge: Cambridge University Press.

Moravcsik, A. and Vachudova, M. (2005) Preferences, Power, and Equilibrium: The Causes and Consequences of EU Enlargement. In: F. Schimmelfennig and U. Sedelmeier (Eds.) The Politics of European Union Enlargement: Theoretical Approaches. London: Routledge, pp. 198-212. 
Plümper, T. and Schneider, C.J. (2007) 'Discriminatory European Union Membership and the Redistribution of Enlargement Gains', Journal of Conflict Resolution 51(4): 568-587.

Schimmelfennig, F. (2014) 'EU enlargement and differentiated integration: discrimination or equal treatment?', Journal of European Public Policy 21(5): 681-698.

Schimmelfennig, F., Leuffen, D. and Rittberger, B. (2015) 'The European Union as a system of differentiated integration: interdependence, politicization and differentiation', Journal of European Public Policy 22(6): 764-782.

Schimmelfennig, F. and Winzen, T. (2014) 'Instrumental and Constitutional Differentiation in the European Union', Journal of Common Market Studies 52(2): 354-370.

Schneider, C.J. (2009) Conflict, Negotiations, and EU Enlargement, Cambridge: Cambridge University Press.

Smeets, S. (2015) 'Unanimity and exposure in the EU Council of Ministers - or how the Dutch won and lost the ICTY debate', European Journal of Political Research 54(2): 288-304.

Winzen, T. (2016) 'From capacity to sovereignty: Legislative politics and differentiated integration in the European Union', European Journal of Political Research 55(1): 100-119.

Winzen, T. and Schimmelfennig, F. (forthcoming) 'Explaining differentiation in European Union treaties', European Union Politics.

\footnotetext{
${ }^{1}$ These are the main (political, economic, and acquis) dimensions of 1993 Copenhagen Criteria for membership.

${ }^{2}$ Some differentiations in accession treaties, such as transition periods in the free movement of workers, could potentially be seen as applying to old member states. However, we have coded them as differentiations for the new countries - as discrimination in the case of free movement - in line with how decision-makers and populations predominantly perceived them.

${ }^{3}$ By exception, in secondary law, these two relatively wealthy and Europhile countries have more exemptions than the Eastern countries in regulatory policies, and as many as the most differentiated Eastern countries in agriculture. In these two areas, adding them to the analysis generates patterns we do not observe in the East (i.e. more exemptive differentiation for richer and Europhile countries).
} 